\title{
METHOD OF LEARNING PERSPECTIVE OF ALALA TANALUL 'ILMA BY IMAM AL-ZARNUJI
}

\author{
Ahmad Busthomy MZ1 , Abdul Muhid ${ }^{2}$ \\ 1, 2 Universitas Islam Negeri Sunan Ampel Surabaya \\ Email: 1busthomyahmad@gmail.com,2abdulmuhid@gmail.com \\ DOI: https://doi.org/10.29313/tjpi.v9i1.6237 \\ Submitted: June 03th, 2020. Approved: June 29th, 2020. Published: June 29th, 2020
}

\begin{abstract}
Before Western experts introduced the method of learning to the world, in fact Islam already had its own method of learning for students. The learning method was written by a medieval Muslim intellectual named Imam al-Al-zarnuji in the book. Alala. This paper aims at knowing the biography of Imam al-Al-zarnuji, the book of Alala and the learning methods offered. The writing method in this research uses library research by taking a variety of literature in accordance with the study. It produced three findings: First al-Al-zarnuji was one of the medieval Muslim intellectuals who had written systematic learning methods before Western experts introduced modern learning methods. Second, the Book of Alala is one of books that contains 37 nadhom, explains about learning methods which are entirely based on religious morals in order to be the good character people. Third, in al-Al-zarniji's opinion, if students want to be successful in getting the benefits of science, there are two things that must be done: (1) it should do the method correctly in taking knowledge; (2) should carry out the requirements in taking knowledge. By doing both of these things, students will get knowledge and get the benefits of the science that they wish.
\end{abstract}

Keywords: Learning Method; Imam al-Zarniji; Alala Book.

\begin{abstract}
ABSTRAK
Sebelum para pakar Barat memperkenalkan metode belajar kepada dunia secara luas, sebenarnya Islam sudah memiliki metode belajar sendiri untuk para pelajar. Metode belajar tersebut telab ditulis oleh salah satu intelektual Muslim abad pertengahan yang bernama Imam al-Al-zarnuji dalam kitab Alala Tanalul Ima. Tulisan ini bertujuan menelaah biografi Imam al-Al-zarnuji, kitab Alala dan metode belajar yang ditawarkan. Adapun metode penulisan dalam penelitian ini menggunakan riset perpustakaan dengan mengambil berbagai literatur yang sesuai dengan kajian. Tulisan ini menghasilkan tiga temuan, yaitu: Pertama, Imam al-Al-zarnuji merupakan salah satu intelektual Muslim abad pertengahan yang telah menulis metode belajar secara sistematis sebelum para pakar Barat memperkenalkan metode belajar modern. Kedua, Kitab Alala merupakan salah satu kitab yang berisi 37 nadhom, membicarakan tentang metode belajar yang secara keseluruhannya didasarkan pada moral religius agar menjadi manusia yang berkarakter baik. Ketiga, dalam pandangan Imam al-Al-zarnuji, apabila para pelajar ingin sukeses mendapatkan manfaat dari ilmu pengetabuan, maka ada dua hal yang harus dilaksanakan, yaitu: (1) hendaknya melakukan dengan benar metode dalam menempub ilmu pengetabuan; (2) bendaknya melaksanakan syarat-syarat dalam menempuh ilmu pengetahuan. Dengan melaksanakan kedua hal tersebut, maka para pelajar akan mendapatkan ilmu pengetabuan serta mendapatkan manfaat ilmu pengetabuan yang dicita-citakan.
\end{abstract}

Kata Kunci: Metode Belajar; Imam al-Zarniji; Kitab Alala. 


\section{PENDAHULUAN}

Pendidikan merupakan suatu hasil peradaban bangsa yang dikembangkan atas dasar pandangan hidup bangsa itu sendiri (nilai dan norma masyarakat) yang berfungsi sebagai filsafat dalam pendidikannya atau sebagai cita-cita dan pernyataan tujuan pendidikannya. Pendidikan bagi kehidupan umat manusia merupakan kebutuhan mutlak yang harus dipenuhi sepanjang hayat. Tanpa pendidikan, sama sekali mustahil suatu kelompok manusia dapat berkembang sejalan dengan aspirasi (cita-cita) untuk maju, sejahtera dan bahagia menurut konsep pandangan hidup mereka (Ihsan, 2010:2)

Dewasa ini, ilmu pengetahuan dan kecanggihan teknologi mengalami perkembangan dan kemajuan yang begitu pesat. Hal ini tentu sangat besar pengaruhnya terhadap pendidikan, karena hampir semua bangsa di dunia sepakat bahwa pendidikan merupakan penentu dalam memajukan sebuah bangsa (Nata, 2011:13; Wirianto, 2013:174). Dampak dari perkembangan pendidikan yaitu munculnya justifikasi positif dan negatif yang dirasakan dalam kehidupan seharihari. Dampak positifnya perubahan dapat dirasakan seperti dekatnya jarak dunia yang dapat dijangkau dengan alat transportasi dan komunikasi modern. Namun, dampak negatif dari perubahan tersebut pun sulit dibendung. Pola pemikiran yang serba rasionalis, agresif, dan empiris akan menjebak manusia dalam kehampaan (nihilis) dan sekuler, bahkan atheis.

Kondisi pendidikan yang demikian, mendorong kita untuk membangun paradigma baru pendidikan yang tidak hanya berorientasi pada ilmu pengetahuan (knowledge oriented) dan keterampilan (skill oriented), namun juga berorientasi pada nilai (values oriented) (Jaya, 2019:18). Proses pendidikan yang mengedepankan akhlak atau nilai-nilai etik tersebut tidak terlepas dari penggunaan metode belajar. Metode pembelajaran (instruction method) merupakan akumulasi konsep-konsep mengajar (teaching) dan konsep belajar (learning). Keduanya merupakan perpaduan dalam sistem pembelajaran yang melibatkan siswa, tujuan, materi, fasilitas, prosedur, alat atau media yang digunakan (Dewi, 2018:44). Setiap proses pembelajaran wajib menggunakan metode-metode pembelajaran agar pembelajaran tersebut dapat maksimal (Roestiyah, 2001; Nasution 2017:10).

Metode belajar adalah cara yang digunakan untuk mengimplementasikan rencana yang sudah disusun dalam kegiatan nyata agar tujuan yang telah disusun tercapai secara optimal (Ma'rifataini, 2018:113). Tentu saja, ada beragam metode belajar yang ditawarkan oleh para pakar pendidikan. Baik tawaran dari para pakar pendidikan modern maupun tradisional semacam pondok pesantren.

Adapun sebuah buku yang menjelaskan metode belajar dan hingga kini masih digunakan beberapa lembaga pendidikan Islam terutama di pesantren yaitu "Kitab Alala Tanalul 'Ilma". Kitab Alala dipandang sebagai salah satu karya intelektual Muslim yang secara khusus membahas tentang metode belajar.

Al-Zarnuji (2011:1) menyatakan bahwa latar belakang menyusun kitab tersebut karena dia telah mengamati banyak para pelajar yang menempuh ilmu pada generasinya, ternyata mereka banyak mendapatkan ilmu pengetahuan tetapi tidak dapat mencapai manfaat buah ilmu pengetahuan, yaitu berupa pengamalan dan penyebaran. Lanjut Al-zarnuji bahwa hal tersebut disebabkan kesalahan mereka ketika menempuh jalan (metode) serta mengabaikan syarat-syarat dalam menempuh ilmu pengetahuan. Kemudian menyusun sebuah kitab yang menjelaskan metode belajar berdasarkan beberapa pengalaman yang diperoleh dari berbagai 
buku serta beberapa petunjuk yang didapatkan dari para gurunya yang kemudian lahirlah kitab tersebut (AlZarnuji, 2011:2). Oleh karena hal inilah, studi ini akan mengkaji metode belajar yang ditawarkan oleh Imam al-Zarnuji.

Sebenarnya telah banyak penelitian yang mengkaji tentang metode belajar menurut Imam al-Zarnuji, antara lain: Pertama, penelitian berjudul "Motivasi Belajar Perspektif Pendidikan Islam Klasik: Studi atas Pemikiran al-Zarnuji” yang dilakukan Suryadi (2012) menitikberatkan pada aspek motivasi dan konsepsi niat pada masa belajar (niyat fi hal al-ta'allum). Kedua, penelitian berjudul "Konsep Pedagogik al-Zarnuji" yang dilakukan Wirianto (2013) memfokuskan pada aspek niat pelajar dan ukuran guru dalam memberikan materi terhadap pelajar. Ketiga, penelitian berjudul "Konsep Adab Belajar Murid Dalam Kitab Ta'lim al-Muta'allim" oleh A. Kholik (2013) yang menyimpulkan beberapa konsep adab belajar yang menjadi pedoman bagi seorang murid. Keempat, penelitian berjudul "Konsep Etika Belajar dalam Pemikiran Pendidikan Islam Klasik" oleh Dedi Mulyasana (2019) menitikberatkan pada petunjuk etika dan akhlak bagi para penuntut ilmu (siswa) dalam melakukan kegiatan belajar mengajar. Kelima, penelitian tentang "Konsep Pendidikan Karakter Dalam Pengembangan Masyarakat Islam (Studi Pemikiran Burhanuddin al-Zarnuji)" oleh Rahmat hidayat (2019) menitikberatkan penerapan metode keilmuan pendidikan karakter sesuai dengan syariat Islam.

Dari beberapa penelitian di atas, tampak studi tersebut masih meneliti secara parsial tentang metode belajar yang ditawarkan oleh Imam al-Zarnuji dalam kitab Ta'lim al-Muta'allim yang sebenarnya memuat 13 pasal. Artinya, kelima penelitian di atas masih mengaitkan salah satu dari 13 pasal yang ditawarkan Imam al-Zarnuji dan belum mengkaji secara menyeluruh. Dengan demikian, dalam penelitian yang penulis lakukan ini akan ada ruang untuk meneliti secara keseluruhan dari metode belajar oleh Imam al-Zarnuji tersebut tetapi hanya fokus pada nadhom-nadhomnya yang telah teringkas menjadi kitab Alala Tanalul 'Ilma.

Untuk memudahkan hal tersebut, maka penelitian ini akan menjawab beberapa hal berikut, antara lain: (1) biografi Imam Al-zarnuji; (2) kitab Alala (3) metode belajar dalam kitab Alala. Selanjutnya, dari penelitian ini diharapkan akan dapat melengkapi berbagai hal yang telah diteliti oleh para peneliti sebelumnya yang hanya mengkaji secara parsial dari metode belajar tawaran Imam al-Zarnuji.

\section{METODOLOGI PENELITIAN}

Penelitian ini merupakan penelitian studi kepustakaan (library research) dengan pendekatan kualitatif. Studi kepustakaan adalah tehnik pengumpulan data dengan mengadakan studi penelaahan terhadap buku-buku, literatur-literatur, catatancatatan dan laporan-laporan yang ada hubungannya dengan masalah yang dipecahkan (Nazir, 2011:27). Artinya, studi ini membatasi kegiatannya hanya pada bahan-bahan koleksi perpustakaan saja tanpa memerlukan riset lapangan. Sedangkan analisis data menggunakan metode analisi isi (content analiring) dan metode deskriptif yaitu memberi gambaran data yang telah terkumpul, sehingga peneliti tidak akan memandang bahwa sesuatu itu sudah memang demikian keadaannya (Suharsimi, 2013:57).

\section{HASIL DAN PEMBAHASAN}

Hasil dari penelitian terbagi dalam tiga hal yaitu (1) Biografi Singkat Imam Alzarnuji (2) kitab Alala (3) Metode Belajar dalam kitab Alala. Nadhom-nadhom 
dalam kitab alala ini tidak dipisahkan dengan pembagian perbab sesuai dengan tema. Jika dianalisis lebih lanjut nadhomnadhom Alala dapat dikelompokkan ke dalam beberapa tema, yakni: 1) Syarat mencari ilmu, 2) Cara mencari teman dan bermasyarakat, 3) Keutamaan ilmu dan orang yang berilmu, 4) Metode mencari ilmu, 5) Keutamaan ilmu fiqih dan bahaya ahli ibadah tanpa ilmu, 6) Motivasi kerja keras dalam belajar, 7) Menjaga lisan, 8) Kedudukan seorang guru, 9) Melatih nafsu, husnuzhon, dan pemaaf, 10) Menghargai waktu dan 11) Keutamaan merantau.

\section{Biografi Singkat Imam al-Zarnuji}

Nama lengkap Imam al-Zarnuji adalah Burhanuddin Ibrahim al-Zarnuji alHanafi. Ada yang menyebut namanya Tajuddin Nu'man bin Ibrahim ibn Khalil al-Zarnuji (Wahyuddin, 2018:555). Kata "al-zarnuji" sendiri dinisbatkan pada salah satu kota kecil di Turki atau menunjuk pada kampung yang masyhur di belakang sungai dataran Turkistan (Abd al-Qodir Ahmad, 1986:2; Suryadi, 2012:54). Sedangkan kata "al-Hanafi" merupakan nisbat nama madzhab yang dianut Imam al-zarnuji, yakni madzhab Hanafi. Adapun dua gelar yang biasa melekat pada diri Imam al-Zarnuji adalah "Burhanuddin", artinya bukti kebenaran agama dan "Burhanul Islam", artinya bukti kebenaran Islam.

Sementara tidak banyak data yang menginformasikan tentang kapan dan dimana kelahiran Imam al-Zarnuji. Imam al-Zarnuji diyakini hidup dalam satu masa dengan beberapa ulama yang dinisbatkan pada "Al-Zarnuji" (sebuah kota Zarnuj, Turki) lainnya (Wirianto 2013:3). Kelahiran atau masa hidup al-Zarnuji hanya dapat diperkirakan lahir pada sekitar tahun 570 H (Sodiman, 2013:58). Namun melihat dari nisbahya, al--Zarnuji berdasarkan data dari para peneliti mengatakan bahwa beliau berasal dari zarnuj, suatu daerah yang dikenal hingga kini dengan nama Afghanistan (Baharuddin, 2008:49).

Imam al-Zarnuji adalah tokoh pendidikan abad pertengahan yang mencoba memberikan solusi bagaimana pendidikan tidak hanya berorientasi pada keduniawian, akan tetapi berorientasi pada akhirat (Suryadi, 2012:53). Beliau termasuk ulama yang hidup pada zaman kemerosotan atau kemunduran Daulah Abbasiyah. Zaman ini disebut juga periode kedua Daulah Abbasiyah, yaitu sekitar tahun 292-658 H (Jaya, 2019:20). AlZarnuji hidup pada seperempat akhir abad ke-6 sampai pada dua pertiga pertama dari abad ke-7 H (menjelang abad 12 - awal abad 13 Masehi) (Sodiman, 2013:59). Adapun tahun wafat Imam al-Zarnuji itu masih harus dipastikan, karena ditemukan beberapa catatan yang berbeda-beda, yaitu tahun 591H, 593H, dan 597H (As'ad, 2007:2).

Imam al-Zarnuji belajar kepada para ulama besar waktu itu. Antara lain, seperti disebut dalam Ta'limul Muta'alim sendiri, adalah (Nizar, 2002:25):

Burhanuddin Ali bin Abu Bakar alMarghinani, ulama besar bermazhab Hanafi yang mengarang kitab al-Hidayah, suatu kitab fiqih rujukan utama dalam mazhabnya. Beliau wafat tahun 593H/1197M.

Ruknul Islam Muhammad bin Abu Bakar, populernya dengan gelar Khowahir Zadeh atau Imam Zadeh. Beliau ulama besar ahli fiqih bermazhab Hanafi, pujangga sekaligus penyair, pernah menjadi mufti di Bochara dan sangat masyhur fatwa-fatwanya. Wafat tahun 573/1177M.

Syaikh Hammad bin Ibrahim, seorang ulama ahli fiqih ahli fiqih bermazhab Hanafi, sastrawan dan ahli kalam. Wafat tahun 576H/1180M.

Syaikh Fakhruddin al-kayani, yaitu Abu Bakar bin Mas'ud al-Kasyani, ulama ahli fiqih bermazhab Hanafi, pengarang kitab Bada-I'us Shana-i. Wafat tahun 587H/1191M. 
Syaikh Fakhruddin Qadli Khan alOuzjandi, ulama besar yang dikenal sebagai mujtahid dalam mazhab Hanafi, dan banyak kitab karangannya. Beliau wafat tahun $592 \mathrm{H} / 1196 \mathrm{M}$.

Ruknuddin al-Farghani yang digelari al Adib al-Muktar (sastrawan pujangga pilihan), seorang ulama ahli fiqih bermazhab Hanafi, pujangga sekaligus penyair. Wafat tahun $594 \mathrm{H} / 1198 \mathrm{M}$.

Karya termasyhur Imam alZarnuji adalah Kitab Ta'lim al-Muta'allim yang menjelaskan tentang metode belajar bagi para pelajar. Kitab ini telah diberi syarah (komentar) oleh Al-'Allamah al-Jalil al-Syekh Ibrahim bin Ismail, dengan nama Syarh Ta'lim al-Muta'allim Tariq alTa'allum dan oleh Syekh Yahya bin Ali bin Nashuh (1007 H/ 1598M) ahli nadhom Turki dan Imam Abdul Wahab al-Sya'rani ahli tasawuf dan al-Qadli Zakaria alAnshari (Yunus, 1990:155; Jaya, 2019:21).

\section{Kitab Alala Tanalul 'Ilma}

Kitab Alala merupakan salah satu kitab yang tidak hanya membicarakan tentang metode belajar, namun juga membahas tentang tujuan belajar, prinsip belajar, strategi belajar dan lain sebagainya yang secara keseluruhannya didasarkan pada moral religius agar menjadi manusia yang berkarakter baik. Kitab Alala ini diterbitkan oleh pondok pesantren Lirboyo Kediri dan tidak tercantum nama pengarangnya. Sebagian cetakan tertulis "li ba'dhi at-talamidz bi fasantrin agung lirboyo Kediri", yang menjadi tanda bahwa penyusunnya adalah salah satu santri dari pesantren Lirboyo Kediri dengan menerjemahkannya ke Arab pegon. Kitab Alala terdiri dari satu jilid dan terdapat 8 halaman, bait nadhom berjumlah 37 bait. Susunan nadhom Alala diawali dengan nadhom-nadhom yang bertema memperingatkan para pencari ilmu akan hal-hal pokok atau syarat-syarat yang harus terpenuhi dalam mencari ilmu.

Nadhom-nadhom dalam kitab Alala ini tidak dipisahkan dengan pembagian perbab yang sesuai dengan tema. Akan tetapi, jika dianalisis lebih lanjut nadhom Alala dapat dikelompokkan dalam beberapa tema, seperti yang telah disebutkan (pada hasil penelitian). Sebagian besar dari nadhom-nadhom dalam kitab Alala termuat dalam kitab Ta'lim al-Muta'allim karya Imam alZarnuji. Sebagian juga termuat dalam kitab-kitab klasik, seperti kitab Nashoibul Ibad, Hasyiab I'anah al- Thalibin, Maroqil Ubudiyah, Syarah Uqudil Juman, Ibya' Ulumiddin, Hasyiah Sittin, Adab al-Dunya Waddin, Al-Majmu', dan Ghodzaul Albab. Sedangkan penggubah atau pengarang tiap-tiap nadhom Alala ini berbeda-beda. Ada yang di digubah oleh Sayyidina Ali bin Abi Thalib, Syeikh Adiy bin Zaid, Syeikh Muhammad bin al-Hasan, Syeikh Ibrahim bin Muhammad bin Abdullah bin al-Hadi, Syeikh Abu Bakar Ahmad bin Muhammad al-Dinuri, Syeikh Abu Bakar bin Kholaf alLakhomi, Imam Kholil bin Ahmad, Syeikh Ali bin Muhammad al-Tihami, dan khalifah Umar bin Abdul Aziz.

Dapat disimpulkan bahwa, kitab Alala ini merupakan ringkasan tentang metode belajar seorang pencari ilmu yang berbentuk nadhom, yang diambil dari beberapa kitab kemudian diterjemah ke bahasa Jawa ditulis dengan menggunakan Arab pegon.

Kitab Alala yang tercantum dalam kitab Ta'lim al-Muta'alim berjumlah 22 nadhom, dan yang tidak tercantum dalam Ta'lim berjumlah 15 nadhom, yaitu sebagai berikut: 
Tabel 1. Kitab Alala Tanalul 'Ilma

\begin{tabular}{|c|c|c|c|c|}
\hline No & Bunyi Nadhom & $\begin{array}{l}\text { Ta'lim } \\
\text { Fasal Ke }\end{array}$ & Digubah Oleh & $\begin{array}{l}\text { Termuat } \\
\text { juga dalam } \\
\text { Kitab }\end{array}$ \\
\hline 1 & سألنيك لاتتال العنم إلابستة * * & \multirow[t]{2}{*}{3} & \multirow{2}{*}{$\begin{array}{l}\text { Ali bin Abi Thalib, ada } \\
\text { pendapat digubah oleh } \\
\text { Imam al-Syafi'i, }\end{array}$} & \multirow[t]{2}{*}{-} \\
\hline 2 & و ذارشاء استاذ وطرص واصطبار وبلغة ز & & & \\
\hline 3 & 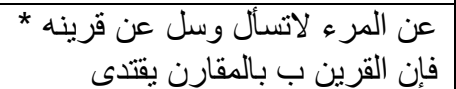 & \multirow[t]{2}{*}{3} & \multirow[t]{2}{*}{ Adiy bin Zaid } & \multirow[t]{2}{*}{$\begin{array}{l}\text { Nashoihul } \\
\text { Ibad }\end{array}$} \\
\hline 4 & فإن كان ذاخير فقارنه تهندى & & & \\
\hline 5 & 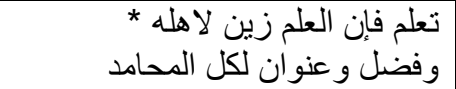 & \multirow[t]{2}{*}{1} & \multirow{2}{*}{$\begin{array}{l}\text { Muhammad bin al- } \\
\text { Hasan murid senior } \\
\text { Imam Hanafi }\end{array}$} & \multirow[t]{2}{*}{-} \\
\hline 6 & 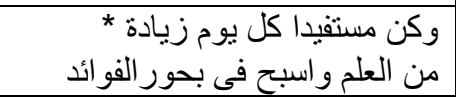 & & & \\
\hline 7 & 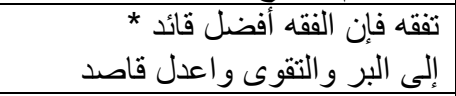 & \multirow[t]{3}{*}{3} & \multirow{3}{*}{$\begin{array}{l}\text { Muhammad bin al- } \\
\text { Hasan murid senior } \\
\text { Imam Hanafi }\end{array}$} & \multirow[t]{3}{*}{$\begin{array}{l}\text { I'anah al- } \\
\text { Thalibin }\end{array}$} \\
\hline 8 & 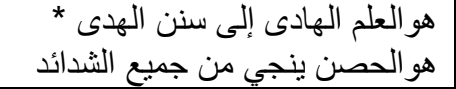 & & & \\
\hline 9 & 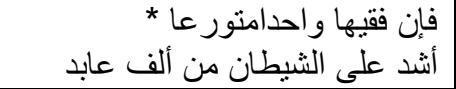 & & & \\
\hline 10 & فو اكباد كنير عاهلم منتسك & \multirow[t]{2}{*}{2} & \multirow{2}{*}{$\begin{array}{l}\text { Syeikh Ibrahim bin } \\
\text { Muhammad bin } \\
\text { Abdullah bin al-Hadi }\end{array}$} & \multirow[t]{2}{*}{-} \\
\hline 11 & 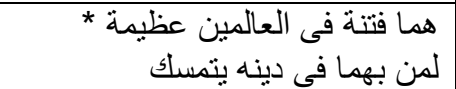 & & & \\
\hline 12 & 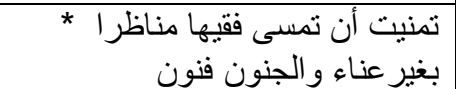 & \multirow[t]{2}{*}{5} & \multirow[t]{2}{*}{$\begin{array}{l}\text { Abu Bakar Ahmad bin } \\
\text { Muhammad al-Dinuri }\end{array}$} & \multirow[t]{2}{*}{-} \\
\hline 13 & تحملها فالعلم كيف يكون المال دون مشقة * & & & \\
\hline 14 & 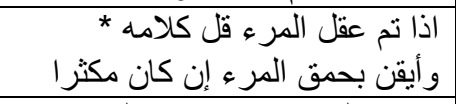 & 15 & Imam Fudhail bin Iyadl & - \\
\hline 15 & 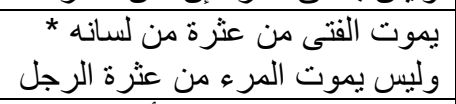 & \multirow[t]{2}{*}{-} & \multirow{2}{*}{$\begin{array}{l}\text { Abu Bakar bin Kholaf } \\
\text { al-Lakhomi, sumber } \\
\text { lain Ali bin Abi Thalib }\end{array}$} & \multirow[t]{2}{*}{$\begin{array}{l}\text { Maroqil } \\
\text { Ubudiyah }\end{array}$} \\
\hline 16 & و وعثرته من فيله ترمى بر أسه * & & & \\
\hline 17 & أخو العلم حى خالد بعد موته التراب رميم & \multirow[t]{2}{*}{5} & \multirow[t]{2}{*}{ Abdurrahman al-Suyuti } & \multirow{2}{*}{$\begin{array}{l}\text { Syarah } \\
\text { Uqudul } \\
\text { Juman }\end{array}$} \\
\hline 18 & الثرى * يظن ميت الاحياء وهو عديم على & & & \\
\hline 19 & 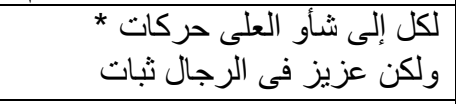 & 3 & - & $\begin{array}{l}\text { Ihya' } \\
\text { Ulumiddin }\end{array}$ \\
\hline 20 & 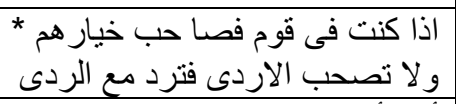 & \multirow[t]{3}{*}{-} & \multirow[t]{3}{*}{-} & \multirow{3}{*}{$\begin{array}{l}\text { Hasyiah } \\
\text { Sittin }\end{array}$} \\
\hline 21 & و أقدم أستاذى عنى على نفس والدى الفض و الثرف & & & \\
\hline 22 & 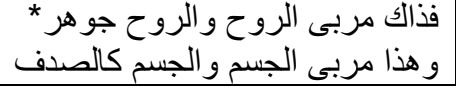 & & & \\
\hline
\end{tabular}




\begin{tabular}{|c|c|c|c|c|}
\hline 23 & 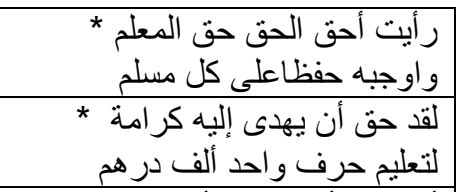 & 3 & $\begin{array}{l}\text { Sayyidina Ali bin Abi } \\
\text { Thalib }\end{array}$ & - \\
\hline 25 & 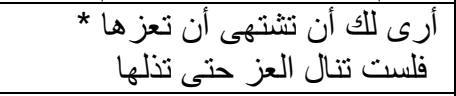 & 10 & - & - \\
\hline 26 & 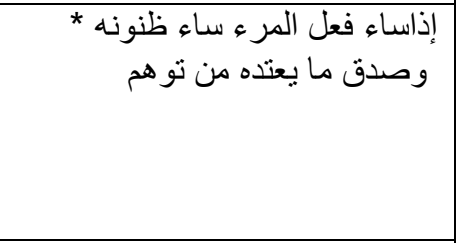 & 9 & al-Mutanabbi & $\begin{array}{l}\text { Ihya' } \\
\text { Ulumiddin, } \\
\text { syarah } \\
\text { Uqudul } \\
\text { Juman }\end{array}$ \\
\hline 27 & 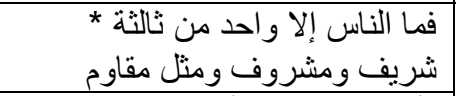 & - & Imam Kholil & $\begin{array}{l}\text { Adab al- } \\
\text { Dunya }\end{array}$ \\
\hline 28 & 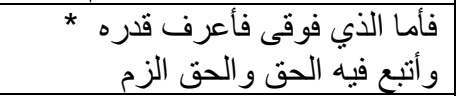 & & & Waddin \\
\hline 29 & 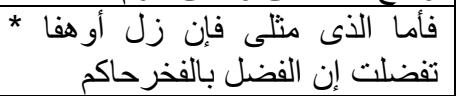 & & & \\
\hline 30 & 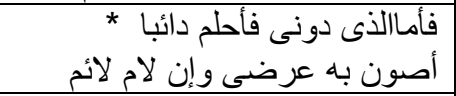 & & & \\
\hline 31 & 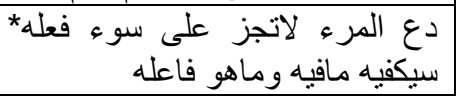 & - & - & - \\
\hline 32 & أليست من الخسران أن لياليا * مري & 13 & $\begin{array}{l}\text { Ali bin Muhammad al- } \\
\text { Tihami }\end{array}$ & - \\
\hline 33 & 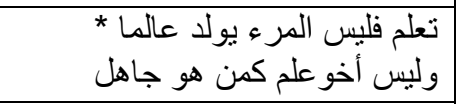 & - & $\begin{array}{l}\text { khalifah Umar bin } \\
\text { Abdul Aziz }\end{array}$ & al-Majmu’ \\
\hline 34 & ت تغرب عن الاوطفار خس في فو ائد العلا & - & Imam Syafi'i & $\begin{array}{l}\text { Ghodzaul } \\
\text { Albab }\end{array}$ \\
\hline 35 & 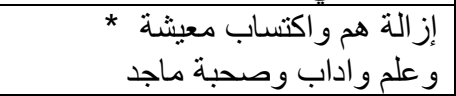 & & & \\
\hline 36 & 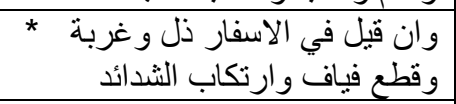 & & & \\
\hline 37 & 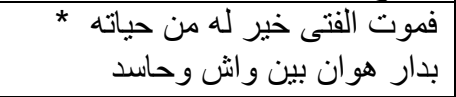 & - & Imam Syafi'i & $\begin{array}{l}\text { Ghodzaul } \\
\text { Albab }\end{array}$ \\
\hline
\end{tabular}

\section{Metode Belajar dalam kitab Alala}

Kata metode dalam bahasa Indonesia diadopsi dari kata methodos dalam bahasa Yunani, kata ini terdiri dari kata meta yang berarti menuju, melalui, mengikuti, sesudah; dan kata hodos yang berarti jalan, perjalanan, cara, atau arah. Metode berarti jalan yang dilalui untuk mencapai tujuan(Arifin, 1996:61; Asy'ari, 2014:195). Dalam bahasa Arab metode diterjemahkan dengan thariqah (Munawwir, 1997:849). Al-thoriqoh berarti jalan, manhaj berarti sistem, dan al-wasilah berarti perantara atau mediator (Nata, 2000:93).
Dalam Kamus Lengkap Bahasa Indonesia diartikan sebagai cara sistematis dan berfikir secara baik untuk mencapai tujuan (Kebudayaan, 1995:652).

Sedangkan istilah belajar dalam bahasa Arab adalah "ta'allum" dari kata kerja "ta'allama-yata'allamu" mempunyai faidah "littakalluf" yang berarti untuk menghasilkan segala sesuatu yang diajarkan (Ali, 2005:22). Dengan demikian, metode belajar adalah cara sistematis untuk mencapai tujuan yang diajarkan berupa ilmu pengetahuan. 
Adapun metode belajar (thariq alta'allum) dan syarat-syarat (syaraith alta'allum) bagi para pelajar yang ingin berhasil tersebut dalam Kitab Alala terbagi dalam beberapa tema. Pengelompokan tema ini tidak berdasarkan urutan nadhom, namun berdasarkan kesamaan pesan yang disampaikan.

Nadhom 1 dan 2 tentang syarat mencari ilmu yang ada enam: Cerdas, semangat, sabar, biaya, petunjuk ustadz dan waktu yang lama.

Nadhom ke 3, 4, 20, 27, 28, 29 dan

30 tentang lingkungan, cara mencari teman bergaul, yaitu harus memilih teman yang memiliki perilaku baik dan tentang cara bermasyarakat, bagaimana cara bersikap dengan orang yang sederajat dengan kita, di atas kita, dan orang yang memiliki derajat di bawah kita.

Nadhom ke 5, 17, 18 dan 33 tentang keutamaan ilmu dan orang yang berilmu.

Nadhom ke 6 tentang metode mencari ilmu, yaitu dengan cara memelihara ilmu yang telah didapat dengan mengingat kembali pelajaran sebelumnya.

Nadhom ke 7, 8, 9, 10 dan 11 tentang keutamaan ilmu fiqih dan bahaya orang yang tekun ibadah tanpa ilmu.

Nadhom ke 12, 13 dan 19 membahas tentang motivasi untuk kerja keras dalam belajar. Ketika seseorang ingin mendapatkan sesuatu maka ia harus berusaha untuk memperolehnya. Semakin besar apa yang diinginkan, maka semakin besar pula perjuangan yang harus dilakukan.

Nadhom ke 14, 15 dan 16 memberikan nasehat tentang menjaga lisan.

Nadhom ke 21, 22, 23 dan 24 membahas tentang kedudukan seorang guru. Guru memiliki kedudukan yang lebih tinggi dari orang tua kandung.

Nadhom ke 25, 26 dan 31 tentang melatih nafsu, husnuzhon, dan pemaaf.
Dapat dikatakan poin ini membahas tentang menghindari akhlak tercela.

Nadhom ke 32 tentang menghargai waktu. Kita harus memanfaatkan waktu dengan sebaikbaiknya.

Nadhom ke 34, 35, 36 dan 37 tentang keutamaan merantau. Berikut penjelasan lebih lanjut:

Syarat mencari ilmu dan metode belajar. Nadhom 1: Ingatlab!! Kamu tidak akan memperoleh ilmu (dengan sempurna) kecuali dengan enam * syarat yang semuanya akan kusebutkan dengan jelas.

Nadhom 2: Kecerdasan, semangat, kesabaran, biaya * bimbingan seorang guru, dan waktu yang cukup lama.

Nadhom 1 dan 2 memberikan nasehat tentang beberapa syarat yang harus dipenuhi oleh seorang pencari ilmu, agar memperoleh ilmu yang bermanfaat. Ilmu yang bermanfaat adalah ilmu yang bisa menghantarkan pemiliknya pada ketaqwaan kepada Allah SWT.

Berdasarkan nadham di atas ilmu yang bermanfaat dapat diperoleh dengan memenuhi 6 syarat, yakni kecerdasan, memilik semangat, kesabaran, biaya, bimbingan seorang guru, dan waktu yang cukup lama.

\section{Kecerdasan}

Kata ذكاء yang menunjukkan : kecerdasan atau kecerdikan (Munawwir, 1997:449). Hal ini berarti mampu memahami pelajaran dengan baik dan tidak memiliki gangguan berfikir. Teori kecerdasan menyebutkan bahwa intelegensi hanya ada satu faktor umum untuk kemampuan mental yang biasa disebut sebagai "g" atau faktor "g", faktanya intelegensi memiliki beberapa perbedaan. Orang yang lulus dengan baik pada sebuah tes dasar, maka orang tersebut pun baik dalam berbagai bidang. Jika orang tersebut kurang baik dalam menghadapi sebuah tes, maka kurang baik pula dalam bidang lain (Feldman, 2012:345). 
Kecerdasan merupakan kapasitas seseorang untuk memperoleh pengetahuan dan melakukan penalaran abstrak. Sedangkan IQ adalah skor yang didapatkan melalui tes kecerdasan (Boere, 2013:264). Kecerdasan dipengaruhi oleh faktor genetik dan proses perkembangannya. Oleh sebab itu, proses perkembangan dan masa prenatal anak dapat mempengaruhi kecerdasan anak. Kecerdasan yang tinggi juga mempengaruhi kemampuan peserta didik untuk menerima pelajaran yang diperoleh. Kecerdasan dalam nadhom tersebut bahwa cerdas artinya memilik kemampuan menangkap ilmu, bukan berarti harus memilik IQ tinggi (An im, 2015:8).

\section{Memiliki semangat}

Semangat adalah sungguhsungguh dengan bukti ketekunan, mencari ilmu tanpa kesemangatan dan ketekunan tidak akan menghasilkan apa-apa (An im, 2015:9). Semangat memiliki arti roh kehidupan yang menjiwai segala makhluk hidup, baik hidup mampun mati (Kebudayaan, 1995:1300). Dalam keilmuwan psikologi, suatu dorongan yang muncul dari dalam diri adalah motivasi. Motivasi adalah suatu yang menghidupkan, mengarahkan dan mempertahankan perilaku (Ormod.J, 2008:58).

Sabar

Konsep sabar yaitu: 1) Pengendalian diri: menahan emosi dan keinginan, berpikir panjang, memaafkan kesalahan, toleransi terhadap penundaan. 2) Ketabahan, bertahan dalam situasi sulit dengan tidak mengeluh. 3) Kegigihan: ulet, bekerja keras untuk mencapai tujuan dan mencari pemecahan masalah. 4) Menerima kenyataan pahit dengan ihlas dan bersyukur. 5) Sikap tenang, tidak terburuburu (Subandi, 2011:225).

Mengutip dari sebuah hadits yang diriwayatkan oleh Abu Huroiroh bahwa, rumus dari sabar adalah menahan emosi dan tidak terbawa amarah (Az Zuhaili, 2013:24). Dalam segala kegiatan kesabaran sangat kita butuhkan untuk meraih kesuksesan. Tanpa adanya kesabaran efek destruktif (kehancuran) akan lebih dominan timbul dari pada efek konstruktif (perbaikan). Artinya kesabaran akan banyak menghasilkan keberhasilan, dan ketidaksabaran akan menghasilkan kegagalan (Deni Sutan, 2012:105).

Kesabaran adalah ketabahan dalam menghadapi musibah, ketabahan dalam melaksanakan ketaatan, dan kesabaran dalam menjauhi maksiat (Muhammad Nawawi, 2015:105). Dalam belajar pasti menemui kesulitan-kesulitan, maka kita harus bersabar untuk menghadapi kesulitan tersebut. Disaat belajar pada suatu madrasah atau sekolah pasti ada peraturan yang harus dipatuhi. Kita harus mampu mentaati segala peraturan yang ada di sekolah dan tidak melanggarnya. Begitu juga, ketika sudah faham dengan suatu ilmu, terlebih ilmu agama, maka kita harus patuh dan sabar dalam menjalankan semua perintah agama dan menjahui semua larangannya.

\section{Modal}

Tiga modal utama yang harus dicukupi berupa fisik, psikis dan harta. Modal fisik dalam hal ini adalah kemampuan secara fisik dalam proses belajar. Modal psikis aspek aspek yang dapat mendorong proses belajar. Modal yang terakhir adalah biaya untuk menunjang kebutuhan belajar.

\section{Petunjuk guru}

Bimbingan seorang guru menjadi bukti kuat kebenaran sebuah ilmu. Tanpa melalui bimbingan seorang guru, kebenaran sebuah ilmu masih diragukan. Inilah salah satu kekuatan seorang guru. Ilmu yang dapat dipertanggung jawabkan adalah ilmu yang diperoleh melalui jalur yang jelas (sanad) dan diyakini dapat dipercaya. 


\section{Waktu yang lama}

Artinya orang belajar perlu waktu yang lama. Lama di sini bukan berarti tanpa target, sebab orang belajar harus punya target. Manajemen waktu secara umum merupakan perkembangan dari proses dan alat menambah efisiensi dan produktivitas. Konsep manajemen waktu telah dibahas pada Al-Quran yang mengajarkan untuk menghargai waktu dengan menggunakan kata "demi waktu" yang terdapat pada surat al-Ashr.

\section{Cara mencari teman dan bermasyarakat}

Nadhom 3: Janganlah engkau bertanya tentang kepribadian seseorang, libat saja siapa temannya * Karena sesungguhnya seseorang akan mengikuti apa yang dilakukan temannya.

Nadhom 4: Jika temannya tidak baik maka jaubilah dia secepatnya * Dan jika temannya baik maka dekatilah dia, niscaya kamu mendapatkan petunjuk.

Nadhom 20: Ketika kamu berada di tengah-tengah kaum, maka bertemanlah dengan orang-orang yang baik di antara mereka * dan janganlah berteman dengan orang yang rendah (budinya), sebab kamu bisa menjadi rendah seperti halnya mereka.

Nadhom tersebut memberikan nasehat dalam memilih seorang teman. Teman dan lingkungan sangat berpengaruh dalam keberhasilan dan kegagalan dalam menggapai cita- cita, tidak sedikit kegagalan pelajar yang berpotensi karena salah pergaulan. (Djamarah, 2011:176) menerangkan bahwa faktor yang menentukan hasil belajar secara ekstrinsik adalah lingkungan alami dan sosial budaya. Lingkungan hidup adalah lingkungan tempat tinggal anak didik, hidup dan berusaha didalamnya.

Keberhasilan belajar tidak hanya ditinjau dari hasil akademik yang didapat peserta didik, namun dapat dilihat dari kepribadian. Ditinjau dari psikologi kepribadian, setiap individu mempunyai perbedaan. Secara garis besar, perbedaan dari setiap individu adalah factor bawaan (nurture) dan yang diperoleh dari belajar (narture). Nurture dan narture adalah faktor yang saling melengkapi dalam perkembangan kepribadian (Feldman, 2012:14). Pada sebuah komunitas atau lingkungan baru, ketika hendak berteman dengan seseorang maka kita harus mengetahui perilakunya atau budi pekertinya. Rasulullah SAW bersabda:

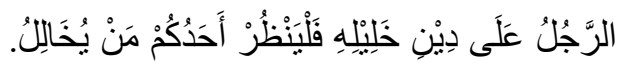

Artinya: "Seseorang itu bergantung pada agama teman akrabnya. Maka hendaklah salah seorang di antara kamu memperhatikan siapa yang dia jadikan teman akrab." (HR. AtTirmidzi, no. 2395).

Seseorang itu mengikuti kebiasaan, cara hidup dan perilaku sahabatnya. Maka hendaknya dia memperhatikan dan merenungkan siapa yang dia jadikan sebagai sahabatnya. Orang yang baik agama dan akhlaknya, hendaknya dia jadikan sebagai sahabat dan tidak dia jauhi. Karena tabiat itu pandai meniru (kebiasaan seseorang) (Al-Muzaidi, 2011:186).

Nadhom 27: Manusia pasti menyandang salab satu dari tiga sifat * (yaitu) lebih mulia, lebib bina dan setara.

Nadhom 28: Terbadap orang yang di atasku (lebih mulia), maka aku mengakui derajatnya*dan mengikutinya dalam hal kebenaran, karena kebenaran adalah kewajiban.

Nadhom 29: Terbadap orang yang setara denganku, maka jika dia tersilap atau berbuat salab * aku akan mengingatkannya,karena mengingatkan itu lebih utama dibandingkan kebanggaan (yakni merasa dirinya lebih baik dari temannya).

Nadhom 30: Terbadap orang yang lebih rendah dariku, maka aku akan bersikap santun (menahan amarab) * aku akan menjaga harga diriku terhadapnya, meskipun ada orang mencerca.

Nadhom 27-30 menerangkan bahwa di dalam masyarakat pasti seseorang menemui berbagai macam 
karakter dari setiap individu. Dengan perbandingan diri sendiri, maka manusia itu terbagi ke dalam tiga tingkatan.

Pertama, mereka yang derajatnya lebih tinggi, dari segi ilmu dan amalnya, orang yang memiliki ilmu dan amal yang tinggi seharusnya didekati dan ditiru sebagai roll model dalam kehidupan, dengan harapan proses meniru digunakan sebagai stimulus perilaku, disebut pula dengan meniru (imitation) atau modeling. Meniru (imitation) atau modeling adalah pembelajaran yang terjadi ketika seseorang mengamati dan meniru perilaku. Dalam pembelajaran ini, tidak ada pembelajaran secara coba-salah seperti pada pengondisian instrumental. Adapun pembelajaran secara pengamatan bisanya memakan waktu yang lebih singkat dari pada pengondisian instrumental (King, 2010:373).

Kedua adalah mereka yang derajatnya sama dengan kita, maka harus menumbuhkan rasa saling pengertian, saling memaafkan, dan saling memahami.

Ketiga adalah mereka yang derajatnya di bawah kita, maka harus kita kasihi dengan memberikan perhatian, dan mengajak kebaikan.

Keutamaan ilmu, orang yang berilmu, dan kedudukan guru

Nadhom 5: Belajarlah, karena ilmu menjadi perbiasan, keutamaan * dan juga menjadi tanda suatu kebaikan bagi pemiliknya.

Nadhom 17: Orang yang berilmu akan tetap bidup setelah matinya * walaupun tulang-tulangnya telah bancur di bawah bumi.

Nadhom 18: Sementara orang yang bodoh telah mati walaupun masib berjalan di atas bumi, disangka dia bidup padahal dia telah tiada.

Nadhom 33: Belajarlab! Manusia tidak dilabirkan dalam keadaan berilmu, dan orang berilmu tidak seperti orang yang tidak. berilmu.

Nadhom diatas memberikan nasehat tentang keutamaan ilmu dan orang yang berilmu. Orang yang memiliki ilmu pengetahuan, memiliki nilai lebih, nilai tersebut dapat diartikan sebagai hadiah. Dalam psikologi hadiah adalah reward yang dapat memunculkan dorongan untuk melakukan sesuatu. Dorongan tersebut adalah motivasi. Motivasi ektrinsik dapat berupa pujian dan hadiah, peraturan, suri tauladan orang tua, dan guru yang dapat mendorong siswa untuk belajar (Sulastri, 2016:174).

Orang yang berilmu akan mendapatkan reward dari Allah SWT berupa ditinggikan derajatnya dalam surat al-Mujadilah 11:

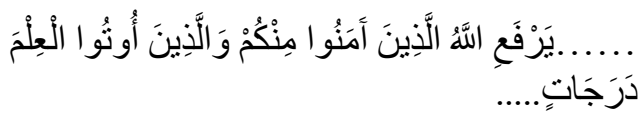

Artinya: ...Allab akan meninggikan orang-orang yang beriman di antaramu dan orang-orang yang diberi ilmu pengetabuan beberapa derajat... (QS. AlMujadilah: 11).

Faktor yang mempengaruhi motivasi intrinsik adalah kebutuhan akan prestasi, pengakuan yang berasal dari lingkungan, pekerjaan yang sesuai dengan apa yang diharapkanya, memiliki keinginan untuk menyelesaikan tugas dengan baik, merasakan kemajuan terhadap apa yang dikerjakan serta lingkungan sosial yang berkembang (Ghufron, 2011:92).

Selain orang yang memiliki ilmu akan memiliki tanda yang berbeda dengan yang lain, dipermudah dalam pekerjaan karena mamiliki ilmu, pemilik ilmu juga akan dikenang walaupun sudah meninggal. Sejarah telah membuktikan bahwa para ilmuwan tetap hidup sepanjang masa meskipun mereka telah tiada berabadabad. Walaupun makna hidup berbeda dengan dengan kehidupan nyata.orang yang berilmu disini adalah orang yang bermanfaat, melakukan kebaikan secara sosial. Dalam pembahasan psikologi, perilaku prososial merupakan perilaku penyokong kesejahteraan orang lain. Didalamnya mengandung unsur 
kedermawanan, persahabatan atau pertolongan.

Orang yang dikenang tentang keilmuwanya dan ancaman bagi orang yang tidak memliki ilmu dapat memunculkan dorongan untuk belajar. Motivasi tersebut merupakan motivasi yang berasal dari luar. Seseorang ingin mendapatkan gelar, kehormatan dan lain sebagainya (Djamarah, 2011:117).

Behaviorisme memandang bahwa pada saat dilahirkan manusia tidak membawa bakat apa-apa. Manusia akan berkembang berdasarkan stimulus yang diterimanya dari lingkungan sekitarnya. Lingkungan yang buruk akan menghasilkan manusia yang baru, lingkungan yang baik akan menghasilkan manusia yang baik (Sobur, 2003:123).

Agar manusia memperoleh derajat dari ilmu, maka harus belajar karena manusia dilahirkan dalam keadaan tidak mengetahui apa-apa dan tidak membawa apa-apa. Manusia lahir bagaikan kertas kosong. Sebagaimana firman Allah SWT dalam Surat an-Nahl ayat 78:

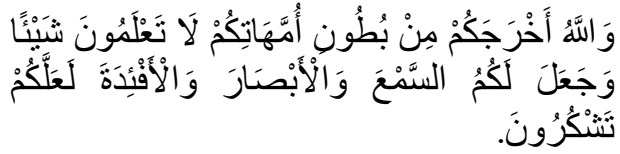

Artinya: "dan Allah mengeluarkan kamu dari perut ibumu dalam Keadaan tidak mengetahui sesuatupun, dan Dia memberi kamu pendengaran, penglibatan dan hati, agar kamu bersyukur (QS. An-Nahl: 78).

\section{Metode atau cara mencari ilmu}

Nadhom 6: Dan jadilah kamu orang yang bisa menggali faedah (manfaat) pada setiap hari atas bertambahnya ilmu * Serta arungilah faedah-faedah ilmu yang laksana lautan.

Nadhom diatas memberikan petunjuk agar setiap hari, sebagai penuntut ilmu mendapatkan tambahan ilmu pengetahuan dan wawasan. Nadhom ini memiliki dua pembahasan mengenai psikologi. Diantaranya adalah :
Proses Kognisi

Secara kognitif, pengetahuan ada suatu informasi yang tersimpan dalam memori dan perlu diingat. Terdapat tiga tahapan ingatan, pertama adalah memasukkan pesan ke dalam ingatan, yang kedua adalah penyimpanan dan ketiga adalah mengingat kembali (King, 2010:402).

Ilmu yang telah kita dapatkan wajib kita jaga dengan memperbanyak muthola'ah, mencatat, dan muroja'ah. Muthola'ah adalah proses memasukkan informasi/ ilmu, sedangkan Muroja'ah merupakan proses mengingat kembali (An `im, 2015:19), untuk memudahkannya disarankan mencatat apa yang sudah dipelajari.

\section{Motivasi}

Motivasi belajar adalah faktor psikis yang sifatnya non intelektual, mempunyai peranan dalam menumbuhkan gairah, perasaan senang, dan bersemangat dalam belajar (Rizqi dkk, 2018:3). Motivasi terbagi menjadi dua yakni ekstrinsik dan intrinsik. Motivasi intrinsik merupakan motivasi yang berasal dari dalam diri, sedangkan motivasi ektrinsik adalah motivasi yang berasal dari luar diri (Santrock, 2009:204).

Agar dapat memunculkan dorongan belajar pada peserta didik, diperlukan pemberian harapan yang realitas, akhirnya ada rasa ingin tahu.

Keutamaan ilmu fiqih dan bahaya orang yang tekun ibadah tanpa ilmu

Nadhom 7: Belajarlab Fikih, karena sesunggubnya Fikih itu pemandu yang paling utama * menuju kebaikan dan ketakwaan, serta tujuan yang paling lurus.

Nadhom 8: Fikih adalah ilmu yang mengantarkan pada jalan-jalan bidayab* dan benteng yang melindungi (pemiliknya) dari segala kesulitan.

Nadhom 9: Sesunggubnya seorang abli Fikih yang wira'i (menjaga diri dari perkara 
haram) * lebih sulit (ditaklukekan) oleh setan, dibandingkan seribu abli ibadah (yang tidak abli Fikib).

Nadhom 10: Sebuab tragedi besar, jika orang berilmu tidak mengamalkan ilmunya * dan tragedi yang lebib besar adalab orang bodoh yang beramal (tanpa ilmu).

Nadhom 11: Keduanya merupakan fitnah yang besar di dunia * bagi orang yang berpegang teguh kepada keduanya dalam urusan agama.

Nadhom ke 7, 8, 9 tentang Ilmu fiqih adalah salah satu ilmu yang sangat penting disamping ilmu tauhid. karena tanpa ilmu fiqih ibadah-ibadah yang kita lakukan tidak akan sah. Oleh karena itu wajib bagi kita mempelajari ilmu fiqih, agar ibadah ibadah yang kita lakukan, muamalah yang kita kerjakan sesuai dengan hukum yang telah di tetapkan oleh Allah SWT.

Nadhom 10 dan 11 menjelaskan tentang bahayanya orang yang bodoh yang tekun beribadah. Golongan yang dipimpin orang yang berilmu, namun perilakunya seperti orang yang tak berilmu, selalu memburu keuntungan dunia dengan ilmu yang mereka miliki. Mereka adalah sumber malapetaka yang besar. Karena mereka dapat merusak moral masyarakat yang luas (Tarobani, 2014:86).

Sebaliknya golongan yang dipimpin oleh orang tak berilmu yang berperilaku saleh dan giat beribadah. Mereka hanya memandang ibadah sebagai tujuan mereka, tidak melihat pentingnya ilmu sebagai dasar ibadah mereka. Ada satu golongan lagi yang dipimpin orang yang tak berilmu dan berperilaku buruk. Ini sangat rawan dengan penyesatan. Golongan ini jauh lebih berbahaya, karena mereka tidak hanya membahayakan moral saja, namun juga membahayakan akidah dan keimanan umat Islam (Tarobani, 2014:84).

\section{Motivasi untuk kerja keras dalam belajar \\ Nadhom 12: Kamu berangan-angan menjadi seorang abli fiqib yang hebat * dengan}

tampa bersusah payah. Berarti kamu telah gila, sebab gila itu bermacam-macam.

Nadhom 13: Harta tidak dapat dicari tanpa jerih payah * maka bagaimana bisa ilmu diraib tanpa jerih payah?

Nadhom 19: Bagi setiap orang untuk (mendapatkan) derajat yang lubur (harus dengan) perjuangan-perjuangan * tetapi sedikit dari mereka yang tabah (dalam perjuangan).

Menerapkan hujjah atau menerapkan ilmu pengetahuan merupakan proses kognitif. Permasalahanpermasalahan yang terjadi di masyarakat membutuhkan penyelesaian. Dalam nadzom ini, menggunakan ibarat ilmu fiqih yang harus diterapkan dalam penyelesaian permasalahan yang ada pada masyarakat. Secara sederhana, informasi yang diperoleh di masyarakat akan diingat dan ilmu pengetahuan yang sudah lama tersimpan dalam memori perlu di ingat kembali untuk menyelesaikan permasalahan yang ada.

Nadhom tersebut juga menjelaskan jika ingin menjadi ahli fiqih dan mampu menerapkan hujjah, maka diharuskan untuk berusaha. Secara sederhana, tidak hanya ahli fiqih saja. Melainkan ahli atau pakar keilmuwan yang ingin menerapkan keilmuwannya maka dibutuhkan usaha. Pada nadhom berikutnya merupakan penguat dari nadzom sebelumnya. Orang yang ingin memiliki harta, dibutuhkan usaha untuk mendapatkan harta tersebut. Jadi, jika ingin menjadi ahli fiqih dan menerapkan hujjahnya atau ingin menjadi ilmuwan dan mempraktikkan keahlianya atau ingin mendapatkan harta, dibutuhkan usaha untuk mencapainya dan mendapatkanya. Tanpa adanya usaha, tujuanya tidak akan tercapai.

Dari penjelasan diatas, dapat ditarik kesimpulan bahwa untuk menjadi ilmuwan, selain memiliki dorongan kebutuhan untuk berprestasi, dibutuhkan proses kerja keras keras. Dalam literatur psikologi dikenal dengan need for achiefment. Sebenarnya istilah ini digunakan untuk 
orang-orang yang bekerja. Namun dalam konteks belajar, dibutuhkan pula kebutuhan akan berprestasi.

Setiap sesuatu yang mulia dan luhur tentu tidak akan mudah untuk didapatkan kecuali dengan perjuangan, kerja keras dan pengorbanan. Untuk mendapat derajat mulia di sisi Allah dengan mencari ilmu sebanyak-banyaknya dan bekerja keras dengan mengamalkan ilmunya serta berkorban atas kesenangankesenangannya demi mendapatkan tempat disisi-Nya (An `im, 2015:35).

Untuk mendapatkan derajat yang tinggi, dalam nadhom ini dapat diartikan sebagai prestasi yang ingin dicapai seseorang, maka dibutuhkan kerja keras atau adanya usaha yang harus dilakukan. Kebutuhan akan prestasi tersebut merupakan kebutuhan need for achiefment. Kebutuan berprestasi merupakan keanekaragaman diantara orang orang dan kedudukan (Uno, 2012:47).

Hal diatas menunjukkan bahwa motivasi seseorang naik turun. Diketahui, faktor faktor yang mempengaruhi motivasi beraneka ragam. Seperti faktor ingin mendapatkan prestasi, mendapat pengakuan, pekerjaan itu sendiri, tanggung jawab, kemajuan dalam bekerja atau harus mengikuti perkembangan. Faktor faktor tersebut yang menyebabkan motivasi tersebut menurun.

\section{Nasehat untuk menjaga lisan}

Nadhom 14: Ketika akal seseorang telah sempurna, maka ia akan sedikit bicara * dan ketika seseorang banyak bicara, maka yakinilah babwa ia orang yang bodoh.

Nadhom 15: Seorang pemuda bisa mati karena tergelincirnya (kesalahan) lisan * dan tidak mati karena terpelesetnya kakinya.

Nadhom 16: Kesalahan lisannya bisa membuat kepalanya tertimpuk batu * namun (sakit karena) tergelincirnya kaki sembuh kemudian.

An تم عقل sebagai kecerdasan. Kecerdasan merupakan kapasitas seseorang untuk memperoleh pengetahuan (yakni belajar dan memahami), mengaplikasikan pengetahuan (memecahkan masalah) dan melakukan penalaran abstrak (Boere, 2013:264). Kecerdasan juga dikatakan sebagai kekuatan akal seseorang dan itu jelas-jelas sangat penting bagi kehidupan manusia karena merupakan aspek dari keseluruhan kesejahteraan manusia.

Sedangkan Akal sangat beragam dan dapat dikelompokkan atas : akal praktis (al-amiat) dan akal teoritis (al alimat). Berdasarkan tinggi jangkauanya dapat dibedakan atas akal material (alaqlu al-hayulani), akal mumkin ('al-aqlu almalakat), akal aktual (al-aqlu bi al-fi ii), dan akal perolehan (al- aqlu al-mustafad). Akan tetapi, kemampuan ini ada batasannya diatas akal ada ilham yang dimensinya lebih tinggi dan mendekati hakikat (Al-Ghozali, 2011:48). Setelah tenggelam dalam tasawuf, al-Ghozali membagi akal ke dalam (a) akal (berfikir dan belajar) dan (b) taklid (mengikuti kepada nabi).

Jika kita membandingkan Akal menurut Al-Ghozali dan kecerdasan menurut Boere yang mana konteks keduanya sama, yakni proses memperoleh pengetahuan. Pemecahan masalah dan penalaran secara abstrak. Pendapat mengenai kecerdasan menurut Boere dapat dibatasi dengan kemampuan dirinya. namun menurut al-Ghozali, akal tidak ada batasnya. Oleh sebab itu pembahasan akal dalam konteks ini terbatas akan kemampuan pada diri seseorang. Dari kedua pendapat ini, akal dan kecerdasan memiliki kesamaan yakni keduanya adalah proses perilaku yang didapat melalui stimulus yang didapat.

Kedudukan seorang guru

Nadhom 21: Aku lebih mengutamakan guruku, dibandingkan orangtuaku * meski aku meraih keutamaan dan kemuliaan dari orangtuaku.

Nadhom 22: Karena guru adalab pendidik (pemelihara) jiwaku, dan jiwa itu 
(ibarat) permata * Sedangkan orangtua adalah pendidik (pemelihara) ragaku, dan raga itu ibarat kulit kerang.

Nadhom 23: Aku yakin dengan seyakin-yakinnya terbadap bak guru * dan mengharuskan setiap umat Muslim agar menjaganya (hak guru).

Nadhom 24: Sungguh guru itu berbak diberi hadiah sebagai tanda penghormatan * atas pengajaran satu buruf (ilmu), dengan seribu dirbam (uang perak).

Guru merupakan seseorang yang berjasa mendidik ruhani anak didiknya, dengan mengenalkan mereka pada kebenaran. Mereka mengajari anak didiknya untuk tidak melihat segala sesuatu hanya dengan mata dan akal saja, karena keduanya sangat terbatas. Mereka mengajari anak didik mereka untuk melihat dengan mata batin atau hati. Sedangkan orang tua adalah seseorang yang mengisi raga dan mental anaknya dengan kasih sayang sehingga dapat terus tumbuh dan bertahan hidup. Orang tua dan guru, keduanya wajib kita hormati. Namun guru memiliki kedudukan pertama yang harus kita hormati, karena guru telah mengisi ruh jiwa seseorang dengan ilmu untuk menuntun raga agar hanya melakukan sesuatu yang baik berdasarkan pandangan Allah SWT melalui firmanNya.

Melatih nafsu, husnuzhon, dan pemaaf

Nadhom 25: Saya melihat kamu mempunyai nafsu yang ingin kamu muliakan * padahal kamu tidak akan mendapat kemuliaan kecuali dengan menghinakan nafsumu.

Nadhom 26: Bila perbuatan manusia

jelek maka akan jelek pula prasangkaprasangkanya * dan akan dibenarkannya kebiasaan-kebiasaan dari kecurigannya.

Nadhom 31: Jangan biraukan orang lain (yang berbuat jahat kepadamu) jangan engkau balas perbuatan jabatnya * Karena dia akan dibalas olaeh perbuatannya.

Nafsu adalah sumber kehancuran bagi manusia yang mengikuti kemauan- kemauannya, nafsu adalah sasaran utama para syetan menghancurkan akal manusia, maka dari itu nafsu harus ditundukkan dan dihinakan agar jangan menuntut hal-hal yang akan merugikan diri kita (An`im, 2015:43).

Dengan kata lain nafsu merupakan suatu yang mengandung dorongan yang mana dalam istilah psikologi dikenal dengan id dalam teori psikoanalisa Freud. Namun jika dilihat dengan teliti, Imam alZarnuji menggandengkan dengan "mulia" sehingga membentuk maksud bahwa setiap orang memiliki nafsu yang mulia. Dari sini didapat bahwa kata "nafsu" dalam konteks ini adalah suatu dorongan yang baik. Namun dalam kalimat selanjutnya nafsu tersebut harus dihinakan. Artinya harus ditundukkan agar tidak menuntut hal-hal yang akan merugikan.

Jihad melawan hawa nafsu merupakan upaya mengendalikan hasrat kejiwaan menuju sesuatu yang baik dan bermnfaat. Setiap amal untuk Allah SWTT. Seperti beribadah, berdzikir membutuhkan usaha yang sungguhsungguh, pemurnian jiwa, keikhlasan dan tekat yang tulus (Az Zuhaili, 2013:55).

Teori Freud mengemukakan bahwa id atau nafsu selalu berprinsip memenuhi kesenangan sendiri (pleasure principle), termasuk didalamnya naluri seks dan agresivitas (Sobur, 2003:113). Oleh sebab itu, Imam al-Zarnuji menganjurkan untuk menundukkan nafsu. Artinya diperlukan kontrol akan dorongandorongan yang datang dari $I d$ atau nafsu.

Untuk mengontrol Id atau nafsu tersebut agar dapat dikontrol, kepribadian manusia memiliki Super ego adalah kata hati atau consecience. Kata hati ini berhubungan dengan lingkungan sosial dan memiliki nilai-nilai moral. Sehingga merupakan kontrol atau sensor terhadap dorongandorongan yang datang dari Id (Sobur, 2003:114). 
Menghargai waktu

Nadhom 32: Bukankah suatu kerugian (besar), ketika hari-hari * berlalu tanpa manfaat, namun dibitung sebagai umur (yang mengurangi jatah usia seseorang).

Nadhom di atas memberikan pesan untuk memanfaatkan waktu sebaik mungkin untuk belajar dan beribadah kepada Allah SWT, terutama pada waktu malam hari, jangan disia-siakan. Kita harus menggunakannya untuk mendekatkan diri kepada Allah dan berdoa kepada-Nya. Sebagai mana firman Allah SWT dalam surat al-Isra' ayat 79 :

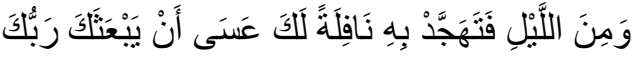

$$
\begin{aligned}
& \text { مَقَامَا مَحْمُودًا }
\end{aligned}
$$

Artinya: "dan pada sebabagian malam hari bersembah yang tahajudlab kamu sebagai suatu ibadah tambahan bagimu; Mudah-mudahan Tubanmu mengangkat kamu ke tempat yang Terpuji (QS Al-Isra’: 79).

Waktu berperan penting dalam proses hidup manusia untuk mencapai kebahagiaan dunia dan akhirat. Siapapun yang menyia-nyiakan waktu niscaya akan merugi (Deni Sutan, 2012:7).

\section{Keutamaan merantau}

Nadhom 34: Menjaublab (berbijrablab) dari daerabmu demi mencari keluburan * dan mengembaralah, karena dalam pengembaraan itu terdapat lima manfaat.

Nadhom 35: Lenyapnya kesusahan, kemudahan rezeki * ilmu, tata krama dan teman yang mulia.

Nadhom 36: Meskipun ada yang menyebut babwa dalam pengembaraan itu terdapat kehinaan dan pengasingan * melanglang buana dan mengalami sengsara.

Nadhom 37: Kematian seseorang lebih baik daripada kebidupannya * di daerab yang dibuni pengadu domba (provokator) dan penghasut (iri hati).

Dalam nadhom tersebut Imam alZarnuji memberikan isyarat untuk merantau. Itu artinya dalam perantauan dibutuhkan kepribadian yang mandiri. Pengembangan kemandirian sangat penting sebab dalam perantauan mengajarkan kedisiplinan, kepedulian terhadap lingkungan dan sikap menghormati orang lain. lima keuntungan bila merantau: menghilangkan kesusahan, mendapatkan bekal atau harta, mendapatkan ilmu, belajar tatakrma dan mencari teman sejati. Kelima keuntungan ini mencari ilmu dan membentuk perilaku manusia.

Dari penjelasan diatas dapat ditarik kesimpulan bahwa anjuran untuk merantau dari rumah agar seseorang belajar kemandirian. Sebab dalam kemandirian tidak bergantung pada orang lain. Ketika menghadapi probematika, seseorang juga dituntut untuk menyelesaikan secara mandiri artinya ia harus nelajar mengenai problem solving.

Proses perkembangan manusia harus dipandang sebagai proses interaksional dinamis. Interaksioanal dinamis mengandung makna bahwa kemandirian berkembang melalui proses proses keragaman manusia dalam kesamaan dan kebersamaan, bukan dalam kevakuman.

\section{KESIMPULAN}

Berdasarkan uraian di atas, maka dapat disimpulkan bahwa Imam al-Zarnuji merupakan salah seorang intelektual abad pertengahan yang menyusun metode belajar secara sistematis sebelum Barat memperkenalkan metode belajar modern. Dalam Kitab Alala Tanalul 'Ilma memuat 37 nadhom sebagai metode belajar yang dia tawarkan kepada para pelajar. Berdasarkan 37 nadhom tersebut, para pelajar diberikan solusi bagi apabila ingin meraih keberhasilan dalam mendapatkan dan memanfaatkan ilmu pengetahuan, maka dia harus memperhatikan dua hal berikut, yaitu: (1) hendaknya melakukan 


\section{Ahmad Busthomy MZ, Abdul Muhid/ Ta'dib: Jurnal Pendidikan Islam, Vol. 9 No. 1 (2020) \\ ISSN 1411-8173 | E-ISSN 2528-5092 \\ https://ejournal.unisba.ac.id/index.php/tadib/article/view/6237}

secara benar ketika menapaki jalan atau metode dalam menempuh ilmu pengetahuan, (2) hendaknya memenuhi syarat-syarat dalam menempuh ilmu pengetahuan.

\section{DAFTAR PUSTAKA}

Abd al-Qodir Ahmad. 1986. Ta'lim AlMuta'allim Thoriq Al-Ta'allum. Kairo: Mathba'ah Sa'adah.

Al-Ghozali, Abu Hamid. 2011. Ibya Ulum Al-Din. Beirut: Dar Al-Fikri.

Al-Muzaidi, Fuad Abdul Aziz Asy-Syalhub dan Harits bin Zaidan. 2011. Panduan Etika Muslim Sehari-Hari. Surabaya: Pustaka Elba.

Al-Zarnuji, Syaikh. 2011. Ta'lim AlMuta'allim. Surabaya: Nurul Huda.

Ali, Muhammad Ma'shum Bin. 2005. Amtsilah At-Tashrifiyah. Semarang: Pustaka Alawiyah.

An`im, abu. 2015. Terjemah Nadzom Alala. -: Mu jizat.

Arifin, Muhammad. 1996. Ilmu Pendidikan Islam. Jakarta: Bumi Aksara.

As'ad, Alliy. 2007. Terjemahan Ta'lim Muta'allim. Yogyakarta: Menara Kudus.

Asy'ari, M. Kholil. 2014. "Metode Pendidikan Islam." JURNAL QATHRUNA Vol. 1 No.1

Az Zuhaili, Wahhab. 2013. Ensiklopedia Akblak Muslim. Jakarta: PT Mizan Publika.

Baharuddin, Esa Nur Wahyuni. 2008. Teori Belajar Dan Pembelajaran. Jogjakarta: Ar Ruzz Media.

Boere, S George. 2013. General Psychology. Jogjakarta: Presmasophie.

Deni Sutan, Bahtiar. 2012. Manajemen Waktu Islami. Jakarta: AMZAH.

Dewi, Erni Ratna. 2018. "Metode
Pembelajaran Modern Dan

Konvensional Pada Sekolah Menengah Atas." PEMBELAJAR: Jurnal Ilmu Pendidikan, Keguruan, Dan Pembelajaran. https://doi.org/10.26858/pembe lajar.v2i1.5442.

Djamarah, Syaiful Bahri. 2011. Psikologi Belajar, Edisi Revisi. Jakarta: PT Rineka Cipta.

Feldman, Robert S. 2012. Pengantar Psikologi. Jakarta: Penerbit Salemba Humanika.

Ghufron, M.R \& Rini Risnawati. 2011. Teori Teori Psikologi. Jakarta: ArRuzz.

Ihsan, Fuad. 2010. Dasar-Dasar Kependidikan:Komponen $M K D K$. Jakarta: Rineka Cipta.

Jaya, Farida. 2019. "PEMIKIRAN PENDIDIKAN ISLAM ALZARNUJI." TAZKIYA Vol.8 No.1.

Kebudayaan, Departemen Pendidikan dan. 1995. Kamus Besar Bahasa Indonesia. Jakarta: Balai Pustaka.

King, Laurs A. 2010. Psikologi Umum: Sebuah Pandangan Apresiatif. Jakarta: Salemba Humanik.

Ma'rifataini, Lisa Diyah. 2018. "IMPLEMENTASI METODE PEMBELAJARAN PENDIDIKAN AGAMA ISLAM (PAI) DI SEKOLAH MENENGAH ATAS NEGERI (SMA) 11 BANDUNG." EDUKASI: Jurnal Penelitian Pendidikan Agama Dan Keagamaan. https://doi.org/10.32729/edukas i.v16i1.464.

Muhammad Nawawi, Ibnu Umar Al-Jawi. 2015. Nashaibul Ibad. Surabaya: thoha putra. 
Munawwir, Ahmad Warson. 1997. Kamus Munawnir Arab-Indonesia Terlengkap. Surabaya: Pustaka Progressif.

Nasution, Mardiah Kalsum. 2017. "Penggunaan Metode Pembelajaran Dalam Peningkatan Hasil Belajar Siswa." STUDLA DID AKTIKA: Jurnal Ilmiah Bidang Pendidikan.

Nata, Abuddin. 2000. Pemikiran Para Tokoh Pendidikan Islam. Seri Kajian Filsafat Pendidikan Islam.

2011. "Prespektif Islam Tentang Strategi Pembelajaran." Jurnal Pendidikan.

Nazir, Moh. 2011. Metode Penelitian. Jakarta: PT. Ghalia Indonesia.

Nizar, Samsul. 2002. Filsafat Pendidikan Islam. Jakarta: Ciputat Press.

Ormod.J, Ellis. 2008. Psikologi Pendidikan. Jakarta: Penerbit Erlangga.

Rizqi, Annisa Afiananda, Yusmansyah, and Shinta Mayasari. 2018. "Faktor-Faktor Yang Mempengaruhi Motivasi Belajar The Factors That Influence Students ' Learning Motivation." Jurnal FKIP Universitas.

Roestiyah. 2001. Strategi Belajar Mengajar. Jakarta: Rineka Cipta.

Sobur, A. 2003. Psikologi Umum. Bandung: Pustaka Setia.

Sodiman. 2013. "ETOS BELAJAR DALAM KITAB TA'LIIM ALMUTA'ALLIM THAARIQ ALTA'ALLUM KARYA IMAM ALZARNUJI." Al-Ta'dib Vol. 6 No.

Subandi. 2011. "Sabar: Sebuah Konsep Psikologi." JURNAL PSIKOLOGI VOLUME 38,

Suharsimi, Arikunto. 2013. "Prosedur Penelitian: Suatu Pendekatan Praktik (Edisi Revisi)." Jakarta:
Rineka

Cipta. https://doi.org/10.1017/CBO9781 107415324.004 .

Sulastri, Anik. 2016. "PENGARUH AKTIFITAS SISWA DALAM PEMBELAJARAN

DAN

MOTIVASI BELAJAR

TERHADAP PRESTASI

BELAJAR SISWA KELAS IX SMP NEGERI 2 KOTA PROBOLINGGO." Jurnal Penelitian Dan Pendidikan IPS (JPPI) Volume 10.

Suryadi, Rudi Ahmad. 2012. "Motivasi Belajar Perspektif Pendidikan Islam Klasik." Ta'lim vol 10 No.1

Tarobani, Shohibun Niam Bin Maulana Al. 2014. Zadah "Bekal Mencari Ilmu Manfaat Dan Berkah. Kendal: AlAziziyyah Press.

Uno, Hamzah.B. 2012. Teori Motivasi \& Pengukuran: Analisis Di Bidang Pendidikan. Jakarta: Bumi Aksara.

Wahyuddin. 2018. "KONSEP PENDIDIKAN AL-GAZALI DAN AL-ZARNUJI." Ekspose Vol 17, No.1

Wirianto, Dicky. 2013. "Konsep Pedagogik Al-Zarnuji."

Yunus, Mahmud. 1990. Sejarah Pendidikan Islam. Jakarta: Hidakarya Agung. 